\title{
10 Assessing responsible food consumption in three Ecuadorian city regions
}

\author{
Myriam Paredes, Donald C. Cole, \\ Fabian Muñoz, Gabriel April-Lalonde, \\ Yubari Valero, Priscila Prado Beltrán, \\ Laura Boada, Peter R. Berti, and \\ the Ekomer project team
}

\section{Introduction}

Most examinations of sustainability of agrifood flows in Latin America have tended to focus on production, distribution, and consumption as separate processes (Gustafson et al., 2016). Such a disarticulated view inhibits the understanding of complex phenomena related to agrifood systems, such as the nutritional transition and the epidemic of obesity in Latin American countries. A more holistic vision of food consumption requires identifying patterns in which the origin of foods, demands of food consumers, and the ways in which provisioning occur are all woven together (Blay-Palmer, 2006; Sonnino, 2009; Csutora \& Vetöné, 2014; see also Chapters 3, 4, 6, 9 , $\& 11$, this volume).

Social, economic, and political pressures reinforce industrialized food systems (Dixon, 2009; Guthman, 2014). On the other hand, food environment characteristics, such as the availability of agroecological spaces, can influence food consumption practices (Brug, 2008). Further, consumers are not homogeneous, either because of limitations in resources or because of active choices. Some individuals, households, and organized groups search out lifestyles and provisioning approaches which are more sustainable, based on differing values and meanings (Stern \& Dietz, 1994; Ozçaglar-Toulouse, 2009; Inglehart, 2015). They go beyond simple market transactions towards concerns about health (Gould, 1988; Moorman \& Matulich, 1993), ecology and environment (Kinnear et al., 1974; Zimmer et al., 1994), corporate social responsibility (Ottman \& Reilly, 1998; Pivato et al., 2008; Feldman \& Reficco, 2015; Tsai et al., 2015; Frynas \& Yamahaki, 2016), ethics (Newholm \& Shaw, 2007; Linders, 2014), and individual social responsibility (Berkowitz \& Lutterman, 1968; Anderson \& Cunningham, 1972). They engage in what we denote here as 'responsible consumption' (Webster, 1975; Antil, 1984; Dueñas Ocampo et al., 2014). 
Although qualitative approaches have been used to understand the motivations of individuals or household members in making decisions to be responsible consumers (see, for instance, Guerrón-Montero \& Moreno-Black, 2001; Piñeiro \& Díaz, 2012; López et al., 2017), limited quantitative research has characterized the extent to which entire populations engage in responsible consumption. Key questions remain: how can one define and measure responsible food consumption among consumers in city region agri-food systems? (see also Chapters 2 and 9, this volume.), and what relationships might consumption have with healthy eating practices? (see Chapter 7 , this volume).

This chapter starts with the context in which we worked, the conceptualization of dimensions of responsible food consumption, and the empirical approach that we took to assessment. We then share our initial results of measurement of the dimensions and the overall Responsible Consumption Index (RCI) and its relation to healthy eating indicators. We discuss the implications of our work and conclude with potential directions for research and application.

\section{Context}

In Ecuador, 62 per cent of the population between 19 and 60 years of age are overweight or obese (Freire et al., 2014). Closely related is the burden of chronic diseases (GBD, 2017), which in Ecuador have been estimated to cost society $€ 1.5$ billion annually (MIES et al., 2017), approximately 1.5 per cent of GDP. While these chronic diseases are often denoted as noncommunicable, they can nevertheless be socially transmitted conditions, being shared among populations and fostered by industrialized agrifood systems that promote highly processed foods (Allen \& Feigl, 2017).

Ecuador has great potential for resolving both obesity and chronic diseases, as the vast majority of foods consumed are produced in the country, and 60 per cent of these are produced on diversified, family farms (MAGAP, 2016). However, market chains usually involve multiple intermediaries, leaving farm families with insufficient recompense for their production efforts, pushing them to expand the production area devoted to more marketable crops and reduce the area for vegetables, fruits, pulses, and oilseeds for home consumption (Carrión \& Herrera, 2012). Further, diets are predominantly composed of tubers and grains, with low intakes of vegetables and fruits (Freire et al., 2013). In 2008, the government of Ecuador included food sovereignty in its constitution, as one way to reduce or eliminate undernutrition and malnutrition. Its mandate was to promote nutritious food, with a preference for agroecological and organic production, which comes from micro-, small-, and middle-sized peasant production and artisanal fisheries, as well as to foster popular economic organizations (Government of Ecuador, 2010).

The Ekomer research team, a multidisciplinary team of Ecuadorian and international universities and civil society organizations, arose out of both a 
concern for chronic diseases and a recognition of the potential that Ecuador offers for addressing this problem. The team has carried out research to understand the conditions in which social movement campaigns promote responsible consumption and public policies that support it. One challenge was to develop and implement a method to elucidate different 'responsible (food) consumption' patterns in three counties (cantones) centred in city regions (including urban and rural areas) where a citizen campaign for responsible consumption has been particularly active: Ibarra, Quito, and Riobamba in the provinces of Imbabura, Pichincha, and Chimborazo respectively, all in the central Sierra of Ecuador.

Quito's population of 2.2 million is ten times that of Riobamba and twelve times that of Ibarra (INEC, 2010). Of the three provinces, the prevalence of undernutrition, as assessed by stunting (low height for age in 0-5year-olds), is greatest in Chimborazo (49 per cent), followed by Imbabura (35 per cent) and Pichincha ( 29 per cent) - national average is 25.3 per cent (ENSANUT-ECU, 2012). On the other hand, overweight $\left(25 \leq \mathrm{BMI}^{1}<\right.$ $30)$ and obesity $(\mathrm{BMI} \geq 30)$ prevalence among adults $20-59$ years of age is highest in Imbabura (62 per cent), followed by Pichincha ( 55 per cent) and Chimborazo (53 per cent), whereas the national average is 62.8 per cent (ENSANUT-ECU, 2012). Among adolescents, a study that included Quito found that the condition of being overweight was associated with inactivity due to $>28$ hours weekly watching television and high consumption of processed foods (Yépez et al., 2008).

In a national survey of household incomes and expenses (ENIGHURINEC, 2013), neighbourhood stores were the most common location for food purchases but the least common location for purchase of less processed foods. In contrast, fairs (open air markets), where the greatest purchase of non- or minimally processed foods occurred (Muzo et al., 2017, p. 28), were the second most common location for food purchases. At the same time, in the three study counties, the majority of agricultural production is dedicated to consumption within the country, rather than export (INECESPAC, 2017), opening up the possibility of greater self-sufficiency in food production in the food-sheds of the selected counties.

\section{Dimensions of responsible consumption}

Dueñas Ocampo and colleagues (2014) reviewed the history of socially responsible consumption as a concept, from a personal psychological attribute to a collective behaviour that encompasses environmental, ethical, and social concerns linked with purchasing considerations beyond price. They defined a socially responsible consumer as 'one who sees in their consumption the opportunity to conserve the environment and the quality of life in society in a particular, local context' (p. 289). They noted that most studies are strongly influenced by an economic perspective, centred on demand and terms of exchange in the purchasing of products and services. 
In taking a more social perspective on consumption, we have adapted our responsible food consumption concept from Alan Warde's (2005) definition of consumption. Thus, responsible food consumers consciously appreciate and appropriate patterns of production, distribution, use, and recycling of food goods and services, which they render more sustainable. Such responsible consumers are interested in knowing where food comes from, the way in which it was produced, the working relationships involved, and the political and environmental implications of their form of consumption in society at large (Antil, 1984; Newholm \& Shaw, 2007; Dueñas et al., 2014). Here, we add the efforts of consumers to self-organize around ethical values and morals of consumption, and to exert political influence at any stage of the process. Such is the notion of 'co-producer', 'a consumer who knows and understands problems of food production' (Carlos Petrini in Beccaria, 2016).

Focusing on responsible consumption in food systems, Heinisch (2016) emphasizes the importance of considering sustainability in the entire set of relationships across the life cycle of food. A food system consists of all the elements (environment, people, inputs, processes, infrastructures, institutions, etc.) and activities that relate to the production, processing, distribution, preparation and consumption of food, disposal of food waste, and the outcomes of these activities, namely nutrition and health status, socio-economic growth, and equity and environmental sustainability (HLPE, 2014). Research on responsible food consumption is scarce, but 'responsible' is often used interchangeably with 'sustainable' when studying food consumption from this perspective. Sustainable diets, as they have been defined and studied, mainly explore the relationships between eating behaviours, health, and environmental impact indicators (Mertens et al., 2016). In normative terms, sustainable diets are protective and respectful of biodiversity and ecosystems; culturally acceptable and accessible; economically fair and affordable; nutritionally adequate, safe, and healthy; while optimizing use of natural and human resources (Burlingame \& Dernini, 2012). Agroecological production refers to limited use of external inputs, natural resources conservation, equity and social justice, limited geographic distances (local), appropriate to seasonal availability, and healthy for people and ecosystems (Blay-Palmer, 2006; FAO, 2010, 2018; Lang \& Heasman, 2015). Responsible consumption should be oriented towards the broader goal of satisfying the food needs of the entire population of a region in an equitable way, one which maintains the ecological integrity of agroecosystems and the health of the population (Fraňková \& Haas, 2017).

The complexity of the concept of responsible consumption has meant that different researchers have included different dimensions in quantitative instruments. In practice, any one approach to measurement cannot capture all relevant aspects of responsible consumption (Lecompte, 2005), rather there should be efforts to adapt them to particular contexts and needs. In the geographic and cultural context of Ecuador, and according to exploratory 
ethnographic studies with families in Quito (Maas, 2017), we decided to include three dimensions:

1) Direct purchase from producers, as an indicator of contribution to the local community and to smallholder farmers' economy.

2) Preference for agroecological products, as an indicator of a preference for more sustainable ways of food production.

3) Consumption of Andean grains, as an indicator of appreciation of local gastronomic culture.

\section{Dimension One: direct purchase from producers}

For the direct purchase from producers, we consider the locations and forms of procuring foods. As smallholder farmers are the most common type of farmers in Ecuador and they primarily produce diverse products for national consumption (MAGAP, 2016), responsible food consumption must consider the sustainability of their livelihoods. Unfortunately, large chains of intermediaries impact smallholders' livelihoods (Chauveau \& Taipe, 2012), hence direct purchase from producers demonstrates a sense of co-responsibility for smallholders' well-being among consumers. Face-toface meeting of producers and consumers generates a greater sense of solidarity, based on fair prices, increasing the incomes of smallholder producers. Acquiring foods directly promotes virtuous spirals of relationships that have been well documented as short circuits of food commercialization (González et al., 2012; CEPAL, 2014; Craviotti \& Soleno Wilches, 2015; Contreras et al., 2018), alternative circuits of commercialization (Chauveau \& Taipe, 2012), or local agrifood systems (Cerdán, 2014). Hence, various forms of consumer food procurement can bolster community economies: through direct purchase from farmers, at farmers' markets or fairs; through food baskets, as in community supported agriculture; or via meals in restaurants which buy directly from smallholder producers.

\section{Dimension Two: preference for agroecological products}

Dimension Two reflects concern about the way foods are produced. In Ecuador, agrarian reform and agricultural modernization efforts in the 1970s undermined existing knowledge and diverse production practices through the intense promotion of mechanization and synthetic agrochemical inputs and fewer crop varieties (Suquilanda, 2006) leading to erosion, declines in soil quality, and adverse human health impacts (Cole et al., 2007; Sherwood, 2009; Paredes, 2010). To address these challenges, more ecological production practices have been promoted (Fundación Heifer, 2014), including agroecology. Agroecology is based on ecological principles such as the conservation of spatial and temporal biodiversity, sustainable management of soils, recycling of nutrients, use of sustainable energy inputs, 
and biological control of pest populations (Altieri, 1999; Gliessman, 2007; Sarandón \& Flores, 2014). Purchase of agroecological foods fosters both sustainable agrifood systems and environmental balance (FAO, 2018). Hence, consumer purchases of agroecological products is valued in this dimension.

\section{Dimension Three: consumption of Andean grains}

Dimension Three is represented by an indicator of consumption of three highly nutritious Andean grains: quinoa (Chenopodium quinoa), amaranth (Amaranthus caudatus), and chocho (Lupinus mutabilis). These three crops have been cultivated for millennia in the Andes with several varieties adapted to zones with depleted soils and limited water availability (Peralta et al., 2012). Quinoa and amaranth have higher protein and lower carbohydrate content than grains such as rice and wheat, which have become more common in the Ecuadorian diet (Jacobsen \& Sherwood, 2002; Freire et al., 2013). Chocho provides essential fatty acids, approximately 22 per cent by dry weight (Villacrés et al., 2010). Hence, all three grains can contribute to healthy diets and address both under- and over-nutrition in the Ecuadorian population, support production by smallholder farm families, avoid their disappearance in local production, and promote cultural heritage and traditional cuisine (Unigarro Solarte, 2010; Ministerio de Cultura y Patrimonio, 2013).

\section{Empirical approach}

\section{Questionnaire design and surveying}

We designed a household questionnaire to capture the different dimensions of responsible consumption described above. Exploratory ethnographic work provided an opportunity to adapt the questions to the understandings and context of households in Quito (Maas, 2017; see also Chapter 7, this volume). The questionnaire as a whole consisted of 78 questions, which also addressed topics other than responsible consumption: ten questions about general household characteristics, 22 questions about household food acquisition practices, and 36 questions about individual dietary practices and knowledge. Interviewers were trained by the lead authors in two-day workshops, followed by one day of practice interviews. The training included how to select the respondents within the selected households, how to ask each question, and how to record the data on Android tablets. For all data collection, interviewers used Android tablets with a pre-coded interview guide that was constructed using ODK (https://opendatakit.org/). The latter obviates a separate data entry step and permits daily monitoring of incoming data as soon as data are uploaded to a cloud-based server. 
In each of the three study counties, a two-staged, random sample of households was selected to represent both urban (64-74 per cent) and rural (26-36 per cent) populations. First, census sectors, subdivisions of counties defined by the Ecuadorian National Institute of Statistics and Censuses (INEC), were selected randomly. Within each manzana (roughly translates to 'neighbourhood') of the chosen census sector, ten dwellings were chosen randomly. As necessary in multi-household dwellings, one household was chosen randomly within that dwelling. Within each household, we explained the project objectives, sought written consent (authorized by the Bioethics Committee of the San Francisco University of Quito), and interviewed two people: a principal adult respondent who answered questions on food provision in the household, and a second adult respondent of the opposite sex. When there was more than one eligible principal or second adult, we randomized by selecting the one with the most recent birthday. Response proportions were high: Ibarra (1282/1475, 87 per cent), Quito (775/860, 90 per cent), Riobamba (858/896, 96 per cent).

For surveys in agroecological locations, the same team of interviewers visited agroecological fairs, markets, stores, and food basket distribution points. Interviewers approached shoppers as they were exiting after their purchases. They explained the study and, when consent was obtained, conducted the interview immediately, except for a few cases where arrangements were made to visit the shopper later in their homes. After the completion of a survey, the interviewers would repeat the process, approaching the next shopper who had completed shopping. The number of agroecological locations was greater in Quito (37) and Riobamba (11) than in Ibarra (6), resulting in larger numbers of respondents in the first two counties (551,299, and 48 respectively).

\section{Variable and index construction}

For each variable, more points are indicative of responses more positively reflective of that dimension (see Table 10.1).

For each household, the scores for each dimension's variable were reduced to the same range of 0 to 3 . The variables that make up the dimensions are on an ordinal scale, going from the absence of the characteristic to a significant presence (for example, zero consumption of Andean grains, to at least seven times per month). The determination of scales from 0 to 3 was carried out through a validation in an expert consultation (consensual validity) (Kaplan et al., 1976; Roberts et al., 2006). Developing a common four-point scale across the three dimensions allowed us to standardize the value of the indicators and compare the dimensions for each population subgroup directly (as recommended by Sarandón \& Flores, 2014).

The three dimensions were combined into the RCI with different weightings. Our assignation of weights was guided by both the Ecuadorian Andean context and prevalence observed in our surveyed population. As 
Table 10.1 Component dimensions of the Responsible Consumption Index (RCI): variables and scoring system

\begin{tabular}{|c|c|c|c|c|}
\hline \multirow[t]{2}{*}{ Dimension } & \multirow[t]{2}{*}{ Variable } & \multirow{2}{*}{$\begin{array}{l}\text { Responses } \\
\text { considered part } \\
\text { of Responsible } \\
\text { Consumption }\end{array}$} & \multicolumn{2}{|l|}{ Scoring system } \\
\hline & & & Options & Score \\
\hline \multirow[t]{5}{*}{$\begin{array}{l}\text { 1. Direct } \\
\text { purchase } \\
\text { from producers }\end{array}$} & \multirow[t]{5}{*}{$\begin{array}{l}\text { Places of food } \\
\text { procurement }\end{array}$} & \multirow{5}{*}{$\begin{array}{l}\text { Direct purchase } \\
\text { from producer, } \\
\text { purchase } \\
\text { at farmers' } \\
\text { market, fair, or } \\
\text { food basket, } \\
\text { grows own, or } \\
\text { purchases at } \\
\text { agroecological } \\
\text { restaurant }\end{array}$} & $\begin{array}{l}\text { If these } \\
\text { procurement } \\
\text { options are: }\end{array}$ & \\
\hline & & & Important & 3 \\
\hline & & & moderate & 2 \\
\hline & & & minor & 1 \\
\hline & & & rarely or never & 0 \\
\hline \multirow[t]{5}{*}{$\begin{array}{l}\text { 2. Preference for } \\
\text { agroecological } \\
\text { produce }\end{array}$} & \multirow[t]{5}{*}{$\begin{array}{l}\text { Production } \\
\text { approach } \\
\text { for foods } \\
\text { procured }\end{array}$} & \multirow[t]{5}{*}{$\begin{array}{l}\text { Procured foods } \\
\text { produced using } \\
\text { agroecological } \\
\text { methods }\end{array}$} & $\begin{array}{l}\text { If the procured } \\
\text { foods were } \\
\text { produced } \\
\text { using } \\
\text { agroecology } \\
\text { methods: }\end{array}$ & \\
\hline & & & Important & 3 \\
\hline & & & moderate & 2 \\
\hline & & & minor & 1 \\
\hline & & & rarely or never & 0 \\
\hline \multirow{5}{*}{$\begin{array}{l}\text { 3. Consumption } \\
\text { of Andean } \\
\text { grains }\end{array}$} & \multirow{5}{*}{$\begin{array}{l}\text { Consumption } \\
\text { of Andean } \\
\text { grains }\end{array}$} & \multirow{5}{*}{$\begin{array}{l}\text { Consumption of } \\
\text { each of quinoa, } \\
\text { amaranth, and } \\
\text { chocho }\end{array}$} & Times per month & \\
\hline & & & $\geq 7$ & 3 \\
\hline & & & $5-6$ & 2 \\
\hline & & & $2-4$ & 1 \\
\hline & & & $\leq 1$ & 0 \\
\hline
\end{tabular}

smallholder family farms provide the majority of national production, but links between urban and rural areas need strengthening in order to promote both food security and access to healthier foods, we allocated the greatest weight to Dimension One (42 per cent). Given the impact of agroecological food production on the environment, as well as on human health, we assigned the second largest weight to Dimension Two (33 per cent). Only 19 per cent of respondents consumed Andean grains more than three times per month, so we assigned a lower weight of 25 per cent for Dimension Three. A household's RCI was then calculated as:

$\mathrm{RCI}=$ Dimension 1 score $\mathrm{x} 0.42+$ Dimension 2 score $\mathrm{x} 0.33+$ Dimension 3 score $\mathrm{x} 0.25$

Given skewed distributions, rank correlations were calculated among dimensions and the RCI. 


\section{RCI relationships with nutrition relevant practice indicators}

Fruit and vegetable consumption was dichotomized into daily versus not. For active control of table salt in the diet, a score was constructed by allocating one point to each control strategy among: (1) minimize consumption of processed foods; (2) and (3) examine food labels for table salt; (4) do not add salt at the table; (5) and (6) buy foods low in table salt; (7) and (8) add little/no salt when cooking; (9) use other spices instead of salt when cooking; and (10) avoid eating away from home. Summed, the salt control practices score could range between 0 and 10 .

Comparisons of measures of central tendency of the RCI and of these nutrition-relevant practice indicators were carried out across samples and counties using non-parametric tests of inference: Wilcoxon-Mann-Whitney test for the dichotomous fruit and vegetable consumption; and Spearman correlations for RCI and salt control.

\section{Results}

\section{Dimension distribution across different counties and samples}

The descriptive statistics on the dimensions are set out in Table 10.2. Direct purchase from producers (Dimension One) and preference for agroecological produce (Dimension Two) have significantly higher scores for consumers from agroecological fairs than in the general population. For both dimensions, Quito has the highest score among consumers of agroecological fairs, while Riobamba has the highest score among consumers of the general population.

For each dimension and for RCI: lower case superscripts with same letter indicate equivalence across the three counties, within the same sample type (random sample of households and fair sample); UPPER CASE superscripts with same letter indicate equivalence across sample type (random sample of households and fair sample), within the same canton.

For consumption of Andean grains (Dimension Three), the population attending agroecological fairs also had a higher average consumption of traditional Andean foods than the randomly selected general population. Quito had the highest score among consumers of agroecological fairs, while Ibarra had the highest score among consumers of the general population.

Table 10.3 presents the rank correlations between the RCI and the three dimensions that make up the index, differentiated by sample. All correlations are significant $(\mathrm{p}<.0001)$ with the exception of Dimension One (D1) versus Dimension Three (D3) in the fairs sample ( $\mathrm{p}=0.51)$. This is expected since Dimension Two (D2), purchases in agroecological fairs, is usually linked to direct purchasing from farmers (D1), while Andean grain consumption (D3) is not necessarily conditioned on direct or agroecological purchases. 
Table 10.2 Descriptive statistics of three dimensions* and overall RCI, by sample type and county

\begin{tabular}{|c|c|c|c|c|c|c|c|}
\hline \multirow[b]{2}{*}{ Dimension } & & \multicolumn{3}{|l|}{ Random } & \multicolumn{3}{|c|}{ Agroecological Fairs } \\
\hline & & $\begin{array}{l}\text { Ibarra } \\
(n=1284)\end{array}$ & $\begin{array}{l}\text { Quito } \\
(n=769)\end{array}$ & $\begin{array}{l}\text { Riobamba } \\
(n=861)\end{array}$ & $\begin{array}{l}\text { Ibarra } \\
(n=48)\end{array}$ & $\begin{array}{l}\text { Quito } \\
(n=551)\end{array}$ & $\begin{array}{l}\text { Riobamba } \\
(n=299)\end{array}$ \\
\hline $\begin{array}{l}\text { 1- Direct purchase } \\
\text { from producers }\end{array}$ & $\begin{array}{l}\text { Mean (SD) } \\
\text { Median } \\
(\text { Min-Max) }\end{array}$ & $\begin{array}{l}1.26(0.17)^{\mathrm{aA}} \\
1.24 \\
(0.65-1.76)\end{array}$ & $\begin{array}{l}1.08(0.19)^{\mathrm{bA}} \\
1.06 \\
(0.47-2.06)\end{array}$ & $\begin{array}{l}1.27(0.28)^{\mathrm{cA}} \\
1.29 \\
(0.35-2.18)\end{array}$ & $\begin{array}{l}1.42(0.21)^{\mathrm{aB}} \\
1.47 \\
(1.06-2.12)\end{array}$ & $\begin{array}{l}1.52(0.29)^{\mathrm{bB}} \\
1.53 \\
(0.82-2.53)\end{array}$ & $\begin{array}{l}1.42(0.20)^{\mathrm{aB}} \\
1.41 \\
(0.76-2.00)\end{array}$ \\
\hline $\begin{array}{l}2 \text { - Preference for } \\
\text { agroecological } \\
\text { produce }\end{array}$ & $\begin{array}{l}\text { Mean (SD) } \\
\text { Median } \\
\text { (Min-Max) }\end{array}$ & $\begin{array}{l}0.13(0.46)^{\mathrm{aA}} \\
0.00 \\
(0.00-3.00)\end{array}$ & $\begin{array}{l}0.18(0.60)^{\mathrm{aA}} \\
0.00 \\
(0.00-3.00)\end{array}$ & $\begin{array}{l}0.30(0.81)^{\mathrm{bA}} \\
0.00 \\
(0.00-3.00)\end{array}$ & $\begin{array}{l}1.81(1.02)^{\mathrm{aB}} \\
2.00 \\
(0.00-3.00)\end{array}$ & $\begin{array}{l}2.34(0.86)^{\mathrm{bB}} \\
3.00 \\
(0.00-3.00)\end{array}$ & $\begin{array}{l}2.24(0.92)^{\mathrm{bB}} \\
2.00 \\
(0.00-3.00)\end{array}$ \\
\hline $\begin{array}{l}3 \text { - Consumption of } \\
\text { Andean grains }\end{array}$ & $\begin{array}{l}\text { Mean (SD) } \\
\text { Median } \\
\text { (Min-Max) }\end{array}$ & $\begin{array}{l}0.70(0.50)^{\mathrm{aA}} \\
0.75 \\
(0.00-2.75)\end{array}$ & $\begin{array}{l}0.55(0.45)^{\mathrm{bA}} \\
0.50 \\
(0.00-2.75)\end{array}$ & $\begin{array}{l}0.47(0.29)^{\mathrm{cA}} \\
0.50 \\
(0.00-2.00)\end{array}$ & $\begin{array}{l}0.86(0.57)^{\mathrm{aB}} \\
0.75 \\
(0.25-3.00)\end{array}$ & $\begin{array}{l}1.15(0.73)^{\mathrm{bB}} \\
1.00 \\
(0.00-3.00)\end{array}$ & $\begin{array}{l}0.57(0.28)^{\mathrm{cB}} \\
0.50 \\
(0.00-2.25)\end{array}$ \\
\hline $\begin{array}{l}\text { Responsible } \\
\text { Consumption } \\
\text { Index (RCI) }\end{array}$ & $\begin{array}{l}\text { Mean (SD) } \\
\text { Median } \\
\text { (Min-Max) }\end{array}$ & $\begin{array}{l}0.75(0.22)^{\mathrm{aA}} \\
0.71 \\
(0.37-2.03)\end{array}$ & $\begin{array}{l}0.65(0.28)^{\mathrm{bA}} \\
0.58 \\
(0.25-2.01)\end{array}$ & $\begin{array}{l}0.75(0.33)^{\mathrm{CA}} \\
0.67 \\
(0.17-1.94)\end{array}$ & $\begin{array}{l}1.41(0.42)^{\mathrm{aB}} \\
1.41 \\
(0.59-2.38)\end{array}$ & $\begin{array}{l}1.70(0.46)^{\mathrm{bB}} \\
1.78 \\
(0.43-2.53)\end{array}$ & $\begin{array}{l}1.48(0.33)^{\mathrm{aB}} \\
1.56 \\
(0.51-2.12)\end{array}$ \\
\hline
\end{tabular}

*standardized across different dimensions to a range of 0 (low) to 3 (high), but not according to sampling weights. 
Table 10.3 The Rank correlation between the RCI and the three dimensions that make up the index

Spearman correlation coefficients

\begin{tabular}{lllll}
\hline & RCI & $D 1$ & $D 2$ & $D 3$ \\
\hline RCI & & 0.67 & 0.80 & 0.59 \\
D1 (Direct purchase) & 0.61 & & 0.44 & 0.16 \\
D2 (Agroecological preference) & 0.52 & 0.15 & 0.075 & \\
D3 (Andean grains) & 0.63 & 0.01 & 0.075 \\
\hline
\end{tabular}

Note: The values above the diagonal are for the random household sample $(\mathrm{n}=2914)$. The values below the diagonal are for the sample recruited at agroecological fairs $(n=898)$. All correlations are significant $(\mathrm{p}<.0001)$ with the exception of D1 vs D3 in the fairs sample $(\mathrm{p}=0.51)$.

Given the correlations, a similar pattern was observed, with distributions in all three cities further to the right (higher) among those attending agroecological fairs than the general population (see Figure 10.1).

\section{RCI relationships with nutrition relevant practices}

Marked heterogeneity was observed in fruit and vegetable consumption across counties and samples (see column cell percentages in Table 10.4). Those buying food at agroecological fairs on average were more likely to report daily consumption of fruits and vegetables compared to the randomly selected population (higher column percentages in lower row). Although generally those households reporting daily fruit and vegetable consumption had higher RCI scores, exceptions occurred (e.g. Ibarra agroecological fairs' sample). (Within each column ${ }^{\dagger}$ versus ${ }^{\ddagger}$ indicates different values across Fruit \& Vegetable strata (No vs Yes, within columns). Within each Fruit \& Vegetable strata (No row and Yes row): lower case superscripts with same letter indicate equivalence across the three counties, within the same sample type (random sample of households and fair sample); UPPER CASE superscripts with same letter indicate equivalence across sample type (random sample of households and fair sample), within the same canton. All comparisons were made with the non-parametric Wilcoxon-Mann-Whitney test.)

All counties and samples presented very low mean and median scores (less than 1 out of 10) on active control of table salt in the diet. While there were some significant differences (see Table 10.5), the scores were very low in both random and fair samples. The correlation between regular active control over table salt with the RCI scores was also low (from 0.07 to 0.19 ). The scores for actively control table salt in the diet are between 0 to 10 according to control strategies: (1) minimize consumption of processed 


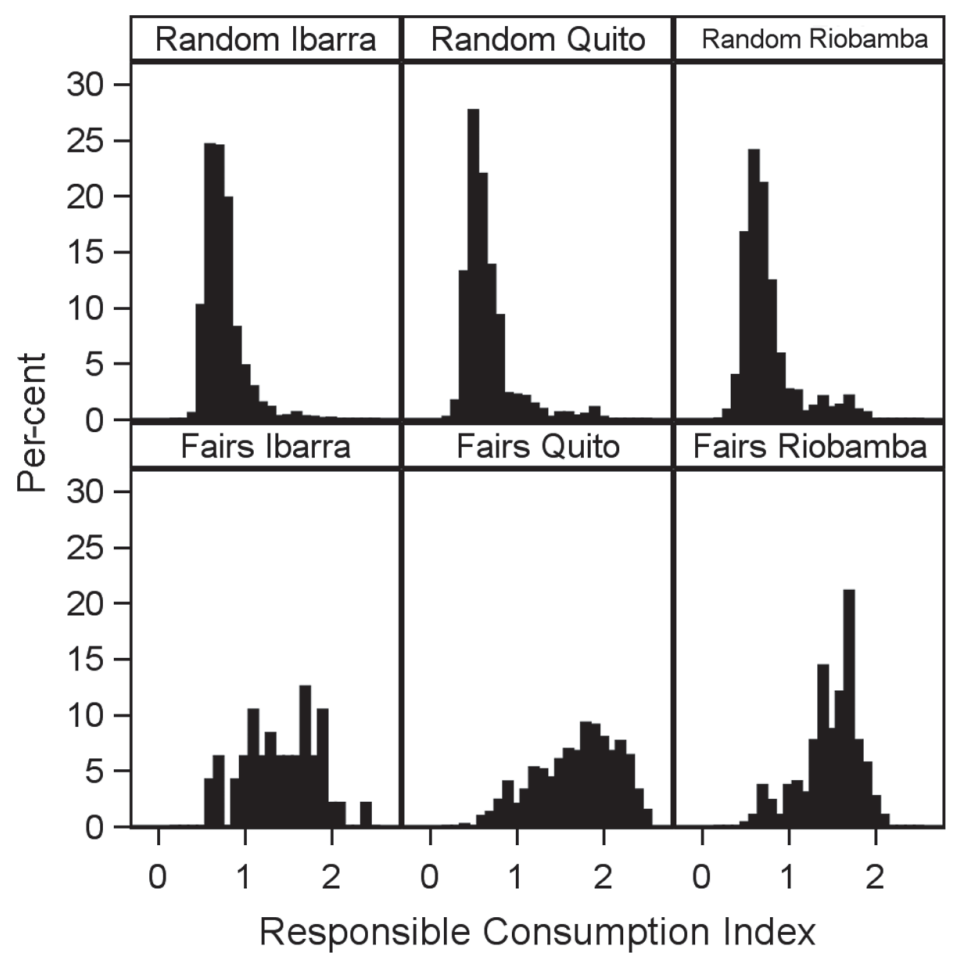

Figure 10.1 Distributions* of RCI by sample type (rows) and county (columns).

* Per cent of sample used to take into account weighting for random samples of households.

foods, (2) and (3) examine food labels for salt/sodium, (4) do not add salt at the table, (5) and (6) buy foods low in salt/sodium, (7) and (8) add little/no salt when cooking, (9) use other spices instead of salt when cooking, (10) avoid eating away from home. (Within the same sample type (random sample of households or fair sample) lower case superscripts with same letter indicate equivalence across the three counties; UPPER CASE superscripts with same letter indicate equivalence across sample type (random sample of households and fair sample), within the same county. All comparisons were made with the non-parametric Wilcoxon-Mann-Whitney test.)

\section{Discussion and implications}

Overall, the results show that food environments of each county have influenced engagement in responsible consumption and decisions on healthy 
Table 10.4 RCI distributions* by fruit and vegetable consumption category, sample and county

\begin{tabular}{|c|c|c|c|c|c|c|c|}
\hline \multirow[b]{2}{*}{$\begin{array}{l}\text { Fruit \& Vegetables } \\
\text { Daily }\end{array}$} & & \multicolumn{3}{|l|}{ Random } & \multicolumn{3}{|c|}{ Agroecological Fairs } \\
\hline & & $\begin{array}{l}\text { Ibarra } \\
(n=1284)\end{array}$ & $\begin{array}{l}\text { Quito } \\
(n=769)\end{array}$ & $\begin{array}{l}\text { Riobamba } \\
(n=861)\end{array}$ & $\begin{array}{l}\text { Ibarra } \\
(n=48)\end{array}$ & $\begin{array}{l}\text { Quito } \\
(n=551)\end{array}$ & $\begin{array}{l}\text { Riobamba } \\
(n=299)\end{array}$ \\
\hline No & $\begin{array}{l}\text { Mean (SD) } \\
\text { Median } \\
\text { (Min-Max) } \\
\% \text { of column }\end{array}$ & $\begin{array}{l}0.72(0.20)^{\mathrm{aA} \dagger} \\
0.68 \\
(0.37-1.91) \\
56.5\end{array}$ & $\begin{array}{l}0.61(0.24)^{\mathrm{bA} \dagger} \\
0.57 \\
(0.25-1.92) \\
46.7\end{array}$ & $\begin{array}{l}0.73(0.32)^{\mathrm{cA} \dagger} \\
0.66 \\
(0.17-1.94) \\
83.8\end{array}$ & $\begin{array}{l}1.54(0.38)^{\mathrm{aB}+} \\
1.61 \\
(0.74-2.07) \\
37.5\end{array}$ & $\begin{array}{l}1.62(0.47)^{\mathrm{aB}+} \\
1.71 \\
(0.66-2.43) \\
22.1\end{array}$ & $\begin{array}{l}1.48(0.31)^{\mathrm{abB}+} \\
1.56 \\
(0.51-2.08) \\
80.6\end{array}$ \\
\hline Yes & $\begin{array}{l}\text { Mean (SD) } \\
\text { Median } \\
\text { (Min-Max) } \\
\% \text { of column }\end{array}$ & $\begin{array}{l}0.79(0.29)^{\mathrm{aA} \ddagger} \\
0.74 \\
(0.40-2.03) \\
43.5\end{array}$ & $\begin{array}{l}0.69(0.30)^{\mathrm{bA} \neq} \\
0.61 \\
(0.25-2.01) \\
53.3\end{array}$ & $\begin{array}{l}0.87(0.63)^{\mathrm{aA} \ddagger} \\
0.78 \\
(0.42-1.85) \\
16.2\end{array}$ & $\begin{array}{l}1.34(0.43)^{\mathrm{aB} \dagger} \\
1.25 \\
(0.59-2.38) \\
62.5\end{array}$ & $\begin{array}{l}1.72(0.45)^{\mathrm{bB} \ddagger} \\
1.80 \\
(0.43-2.53) \\
77.9\end{array}$ & $\begin{array}{l}1.49(0.39)^{\mathrm{aB} \dagger} \\
1.56 \\
(0.71-2.12) \\
19.4\end{array}$ \\
\hline
\end{tabular}

* adjusted according to sampling weights. 
Table 10.5 Summary statistics* of table salt control practice scores by sample and county, and correlations between table salt scores and RCI

\begin{tabular}{|c|c|c|c|c|c|c|}
\hline & \multicolumn{3}{|l|}{ Random } & \multicolumn{3}{|c|}{ Agroecological fairs } \\
\hline & Ibarra & Quito & Riobamba & Ibarra & Quito & Riobamba \\
\hline $\begin{array}{l}\text { Salt control practices } \\
\text { Mean }(\text { Std) } \\
\text { Median } \\
\text { (Min-Max) }\end{array}$ & $\begin{array}{l}0.32(0.62)^{\mathrm{aA}} \\
0.00 \\
(0-3)\end{array}$ & $\begin{array}{l}0.68(0.91)^{\mathrm{bA}} \\
0.00 \\
(0-6)\end{array}$ & $\begin{array}{l}0.59(1.23)^{\mathrm{aA}} \\
0.00 \\
(0-6)\end{array}$ & $\begin{array}{l}0.46(0.65)^{\mathrm{aA}} \\
0.00 \\
(0-2)\end{array}$ & $\begin{array}{l}0.74(0.98)^{\mathrm{aA}} \\
0.00 \\
(0-5)\end{array}$ & $\begin{array}{l}0.87(1.40)^{\mathrm{aB}} \\
0.00 \\
(0-6)\end{array}$ \\
\hline $\begin{array}{l}\text { Correlation between sa } \\
\text { Spearman correlation } \\
\mathrm{p} \\
\mathrm{n}\end{array}$ & $\begin{array}{l}\text { ol practices an } \\
0.07 \\
0.008 \\
1284\end{array}$ & $\begin{array}{l}\text { CI } \\
0.15 \\
<.0001 \\
769\end{array}$ & $\begin{array}{l}0.07 \\
0.04 \\
861\end{array}$ & $\begin{array}{l}0.13 \\
0.39 \\
48\end{array}$ & $\begin{array}{l}0.14 \\
0.001 \\
551\end{array}$ & $\begin{array}{l}0.19 \\
0.001 \\
299\end{array}$ \\
\hline
\end{tabular}

*adjusted according to sampling weights. 
food among their population. Here we explore some of the potential reasons for this heterogeneity across counties.

The higher RCI scores for households in Riobamba were driven by the higher scores for Dimensions One (direct purchase from producers) and Two (preference for agroecological produce). The higher value for Dimension Two in Riobamba is consistent with the higher proportion of open markets per capita in Riobamba, where there is 1 open market space per 5,641 families, compared to 1 per 8,111 in Ibarra, and 1 per 19,417 in Quito (Ekomer, 2017).

However, in the group sampled at agroecological fairs, Quito had the highest value for the three dimensions. This likely reflects the strong awareness-raising process of the ' 250 thousand families', a citizens' campaign (www.quericoes.org) which promotes practices of responsible food consumption, focussing on populations involved in agroecological production and direct markets. This might also explain why a higher percentage of consumers in fairs in Quito also consume fruits and vegetables.

Some of the differences observed between the random sample and the fairs sample are due to the nature of the variables considered for Dimensions One and Two. Indeed, as direct and agroecological purchasing sites are often the same, it is expected that consumers sampled in agroecological fairs would obtain a higher score for these dimensions and that they should be more highly correlated. That this is the case is partial validation of the dimensions and RCI.

For Dimension Three, on Andean grains, the Ibarra random sample had a higher score than the other counties. This finding is consistent with Ibarra being a centre of quinoa (Subsecretaría de Agricultura, 2015) and chocho (Peralta, 2016) production, likely influencing consumption among the general population. Nevertheless, agroecological fairs seem to be an effective way of influencing Andean grains consumption, as shown by the high score found in the Quito fairs sample.

Practices aimed at regularly and actively controlling table salt in the diet were uncommon in all counties and both samples, making this potential link between responsible consumption and a nutritionally relevant practice hard to make (with low rank correlations). The positive association between responsible food consumption and (some aspects of) the quality of the diet (that is, fruit and vegetable consumption, but not salt control) is intriguing. Does practising responsible consumption lead to greater fruit and vegetable consumption (perhaps by directing the shoppers to markets where fruits and vegetables are sold)? Or do health concerns increase the pursuit of fruit and vegetables and lead consumers to agroecological markets, which increases the RCI? Whatever the nature of the relationship, it may be expected that if food consumption in Ecuador becomes more 'responsible', it would also become consistent with public health promotion of fruit and vegetable consumption. 


\section{Conclusions and further research}

The RCI represents a valuable tool for characterizing different city region populations and their food procurement and consumption patterns (see also Chapters $9 \& 11$, this volume). The RCI was also useful for establishing a concrete relationship between a more general consumption pattern and some specific behaviour in another domain, such as the consumption of fruits and vegetables. From a methodological perspective, despite the limitations of the RCI, its potential to compare patterns of food consumption with other environmental, economic, social, health, demographic, or other variables opens up a range of possibilities for the study of responsible consumption. The RCI represents both a relatively quick assessment tool and a starting point for further quantitative and qualitative research.

On the other hand, the nature of the quantitative data did not tap into consumer's intentions behind their responsible consumption practices. It may be that a consumer intends to consume responsibly, but does not demonstrate practices that contribute to a sustainable food system. Several barriers (e.g. physical, economic, temporal or cognitive) can explain this gap between intentions and behaviours, including the role of accepted sets of practices, termed by Lahlou (2018) as 'installations'. Conversely, a consumer who contributes to a sustainable food system through his practices may not necessarily be intentional, where the concept of responsible consumption implies a certain awareness, and active choices. Food consumption patterns are motivated by multiple factors and the intention to consume responsibly may not be the one that has motivated a practice that contributes to a sustainable food system. It may be because of the organoleptic qualities of food, the proximity of markets, the incentives of a given public policy, or other reasons. Studies evaluating consumer intentions or combining questions about intentions with observations on actual practices would help to inform the conceptualization and operationalization of responsible food consumption.

The RCI could be useful for testing how the food environment influences food consumption patterns. Shoppers at agroecological fairs tended to have higher responsible consumption indexes. In terms of public policy, this suggests that agroecological markets should be promoted and supported to give more consumers the opportunity to choose responsibly for their food system. Citizens can influence their food environment through campaigns and organizations that promote the creation of neighbourhood, open and agroecological markets, as was shown by the data on Quito. Further applications of the RCI in different contexts may elucidate other patterns and explore different opportunities to understand responsible consumption's contribution to sustainable food systems and better health.

\section{Acknowledgements}

The Ekomer team includes Malek Batel, Pablo Lopez, and Stephen Sherwood. We also thank survey participants and interviewees. 


\section{Note}

1 BMI, Body Mass Index, is calculated as weight (in $\mathrm{kg}$ ) divided by the square of height (in m). A BMI of 25 to 30 is considered overweight, and a BMI over 30 is considered obese. Available at: http://www.who.int/en/news-room/fact-sheets/ detail/obesity-and-overweight. Accessed 22 October 2018.

\section{References}

Allen, L.N. \& Feigl, A.B. (2017) Reframing non-communicable diseases as socially transmitted conditions. The Lancet Global Health. 5(7), pp. 644-646.

Altieri, M. (1999) Applying agroecology to enhance the productivity of peasant farming systems in Latin America. Environment Development and Sustainability. 1(3), pp. 197-217.

Anderson, W.T. \& Cunningham, W.H. (1972) The socially conscious consumer. The Journal of Marketing. 36(3), pp. 23-31.

Antil, J. H. (1984) Socially responsible consumers: Profile and implications for public policy. Journal of Macromarketing. 4(2), pp. 18-39.

Beccaria, S. (2016) Evènement parallèle: Présentation des actions de Slow Food en Méditerranée. Report available at: http://www.fao.org/in-action/quality-andorigin-program/en and https://www.slideshare.net/ExternalEvents/evnementparallle-prsentation-des-actions-de-slow-food-en-mditerrane-s-beccaria-english.

Berkowitz, L. \& Lutterman, K.G. (1968) The traditional socially responsible personality. Public Opinion Quarterly. 32(2), pp. 169-185.

Blay-Palmer, A. (2006) Imagining sustainable food system. In: Blay-Palmer, A. (Ed.) Imagining sustainable food system: Theory and practice. London, Routledge.

Brug, J. (2008) Determinants of healthy eating: Motivation, abilities and environmental opportunities. Family Practice. 25(1), pp. 50-55.

Burlingame, B. \& Dernini, S. (2012) Sustainable diets and biodiversity: Directions and solutions for policy, research and action. Proceedings of the International Scientific Symposium Biodiversity and Sustainable Diets United Against Hunger. 3-5 November, 2010. Rome, FAO.

Carrion, D. \& Herrera, S. (2012) Ecuador rural del siglo XXI. Soberanía alimentaria, inversión pública y política agraria. Instituto de Estudios Ecuatorianos. Quito, Ecuador.

CEPAL [Comisión Económica para América Latina] (2014) Agricultura familiar y circuitos cortos: Nuevos esquemas de producción, comercialización y nutrición. CEPAL, Serie Seminarios y Conferencias (77).

Cerdán, C. (2014) La experiencia de los Sistemas Agroalimentarios Localizados (SIAL) en América Latina. In: Agricultura familiar y circuitos cortos: Nuevos esquemas de producción, comercialización y nutrición. CEPAL, Serie seminarios y conferencias.

Chauveau, C. \& Taipe, D. (2012) Circuitos alternativos de comercialización. Quito, Ecuador, Ministerio de Agricultura, Ganadería Acuacultura y Pesca del Ecuador, AVSF.

Cole, D.C., Sherwood, S., Paredes, M., Sanin, L.H., Crissman, C., Espinosa, P., \& Muños, F. (2007) Reducing pesticide neurotoxic effects in farm households. Internatonal Journal of Occupational and Environmental Health. 13(3), pp. 281-289.

Contreras, J., Paredes, M., \& Turbay, S. (2018) Circuitos cortos de comercialización agroecológica en el Ecuador. Idesia. 35(3), pp. 71-80. 


\section{Paredes et al.}

Craviotti, C. \& Soleno Wilches, R. (2015) Circuitos cortos de comercialización agroalimentaria: Un acercamiento desde la agricultura familiar diversificada en Argentina. Mundo Agrario. 16(33).

Csutora, M. \& Vetöné, M. (2014) Consumer income and its relation to sustainable food consumption - obstacle or opportunity? International Journal of Sustainable Development \& World Ecology. 21(6), pp. 512-518. Available at: http://dx.doi. org/10.1080/13504509.2014.965238.

Dixon, J. (2009) From the imperial to the empty calorie: How nutrition relations underpin food regime transitions. Agriculture and Human Values. 26(4), pp. 321-333.

Dueñas Ocampo, S., Perdomo-Ortiz, J., \& Villa Castaño, L.E. (2014) El concepto de consumo socialmente responsable y su medición. Una revisión de la literatura. Estudios Gerenciales. 30(132), pp. 287-300.

Ekomer (2017) Database of fairs and other agroecological shops in Quito, Ibarra, and Riobamba counties (unpublished).

ENIGHUR-INEC (2013) Encuesta nacional de ingresos y gastos de hogares urbanos $y$ rurales (ENIGHUR 2011-2012). Available at: http://www.ecuadorencifras. gob.ec/encuesta-nacional-de-ingresos-y-gastos-de-los-hogares-urbanos-y-rurales/.

ENSANUT-ECU (2012) Encuesta nacional de salud y nutricion. Available at: http:// www.ecuadorencifras.gob.ec/documentos/web-inec/Estadisticas_Sociales/ ENSANUT/MSP_ENSANUT-ECU_06-10-2014.pdf.

FAO (2010) Sustainable diets and biodiversity directions and solutions for policy, research and action. Rome, FAO. Available at: http://www.fao.org/docrep/016/ i3004e/i3004e.pdf.

FAO (2018) The 10 elements of agroecology. Guiding the transition to sustainable food and agricultural systems. Rome, FAO. Available at: http://www.fao.org/3/ I9037EN/i9037en.pdf.

Feldman, P.M. \& Reficco, E. (2015) Impacto de la responsabilidad social empresarial en el comportamiento de compra y disposición a pagar de consumidores bogotanos. Estudios Gerenciales. 31(137), pp. 373-382.

Francois-Lecompte,A.(2005) La consommationsocialement responsable:Proposition et validation d'un cadre conceptuel intégrateur. These pour l'Obtention du Doctorat en Sciences de Gestion. Universite Pierre Mendes France, Ecole Doctorale de Sciences de Gestion. Grenoble, France. Available at: https://www. researchgate.net/profile/A_Francois-Lecompte/publication/281876972_La_ consommation_socialement_responsable_proposition_d'un_cadre_d'analyse_ integrateur/links/57e231d008ae9e25307d56c3/La-consommation-socialementresponsable-proposition-dun-cadre-danalyse-integrateur.pdf.

Fraňková, E. \& Haas, W. (2017) Socio-metabolic perspectives on the sustainability of local food systems. Cham, Springer.

Freire, W.B., Ramírez, M.J., Belmont, P., Mendieta, M.J., Silva, M.K., Romero, N., Sáenz K., Piñeiros, P., Gómez, L.F., \& Monge, R. (2013) Resumen ejecutivo. Tomo I. Encuesta Nacional de Salud y Nutrición del Ecuador. Quito, Ecuador, ENSANUT-ECU 2011-2013 Ministerio de Salud Pública/Instituto Nacional de Estadística y Censos.

Freire, W.B., Silva-Jaramillo, K.M., Ramírez-Luzuriaga, M.J., Belmont, P., \& Waters, W.F. (2014) The double burden of undernutrition and excess body weight in Ecuador. The American Journal of Clinical Nutrition. 100(6), pp. 1636S-1643S. 
Frynas, J.G. \& Yamahaki, C. (2016). Corporate social responsibility: Review and roadmap of theoretical perspectives. Business Ethics: A European Review. 25(3), pp. 258-285.

Fundación Heifer (2014) La agroecología está presente. Mapeo de productores agroecológicos y del estado de la agroecología en la sierra y costa ecuatoriana. Quito, Ecuador, Fundación Heifer Ecuador y Ministerio de Agricultura, Ganadería, Acuacultura y Pesca (MAGAP).

GBD [Global Burden of Disease Obesity Collaborators] (2017) Health effects of overweight and obesity in 195 countries over 25 years. New England Journal of Medicine. 377(1), pp. 13-27.

Gliessman, S.R. (2007) Agroecology: The ecology of sustainable food systems. 2nd Edition. Boca Raton, FL, CRC Press, Taylor \& Francis Group.

González, I., De Haro, T., Ramos, E., \& Renting, H. (2012) Circuitos cortos de comercialización en Andalucía: Un análisis exploratorio. Revista Española de Estudios Agrosociales y Pesqueros. 232, pp. 193-227.

Gould, S.J. (1988) Consumer attitudes toward health and health care: A differential perspective. Journal of Consumer Affairs. 22(1), pp. 96-118.

Government of Ecuador (2010) Ley Orgánica del Régimen de la Soberania Alimentaria. Available at: https://www.soberaniaalimentaria.gob.ec/pacha/wpcontent/uploads/2011/04/LORSA.pdf.

Guerrón-Montero, C. \& Moreno-Black, G. (2001) Household structure and dietary patterns in the Afro-Ecuadorian highlands. Food and Nutrition Bulletin. 22(1), pp. 23-30.

Gustafson, D., Gutman, A., Leet, W., Drewnowski, A., Fanzo, J., \& Ingram, J. (2016) Seven food system metrics of sustainable nutrition security. Sustainability. 8, pp. 196-213.

Guthman, J., Broad, G., Klein, K., \& Landecker, H. (2014) Beyond the sovereign body. Gastronomica: The Journal of Food and Culture. 14(3), pp. 46-55.

Heinisch, C. (2016) Conceptualizing and creating sustainable food systems: How interdisciplinarity can help. In: Blay-Palmer, A. (Ed.) Imagining Sustainable Food Systems: Theory and Practice. London, Routledge.

HLPE [High Level Panel of Experts on Food Security and Nutrition] (2014) Food losses and waste in the context of sustainable food systems. A report by the HLPE of the Committee on World Food Security, Rome. Available at: www.fao.org/cfs/ cfs-hlpe.

INEC [Instituto Nacional de Estadisticas y Censo] (2010) Censo de población y vivienda. Available at: http://www.ecuadorencifras.gob.ec/censo-de-poblacion-yvivienda/.

INEC-ESPAC (2017) Encuesta de superficie y producción agropecuaria continua (ESPAC). Available at: http://www.ecuadorencifras.gob.ec/documentos/web-inec/ Estadisticas_agropecuarias/espac/espac_2017/Informe_Ejecutivo_ESPAC_2017. pdf. Accessed 12 August 2018.

Inglehart, R. (2015) The silent revolution: Changing values and political styles among western publics. Princeton, NJ, Princeton University Press.

Jacobsen, S. \& Sherwood, S. (2002) Cultivo de granos andinos en Ecuador. Informe sobre los rubros quinua, chocho y amaranto. Organicación de las Naciones Unidas para la Agricultura (FAO), Centro Internacional de la Papa (CIP), y Catholic Relief Services (CRS). Quito, Ecuador. 


\section{Paredes et al.}

Kaplan, R.M., Bush, J.W., \& Berry, C.C. (1976) Health status: Types of validity and the index of well-being. Health Services Research. 11(4), pp. 478-507.

Kinnear, T.C., Taylor, J.R., \& Ahmed, S.A. (1974) Ecologically concerned consumers: Who are they? Journal of Marketing. 38(2), pp. 20-24.

Lahlou, S. (2018) Installation theory: The societal construction and regulation of behaviour. Cambridge, Cambridge University Press.

Lang, T. \& Heasman, M. (2015) Food wars: The global battle for mouths, minds and markets. Second edition. New York, Routledge.

Linders, H. (2014) Consumo ético, consumo saludable: Existe un nuevo consumidor en América Latina? In: Agricultura familiar y circuitos cortos: Nuevos esquemas de producción, comercialización y nutrición. CEPAL, Serie seminarios y conferencias.

López, S., Marín L., \& Ruiz de Maya, S. (2017) Introducing personal social responsibility as a key element to upgrade CSR. Spanish Journal of Marketing- ESIC. 21(2), pp. 146-163.

Maas, V. (2017) Observing responsible food consumption in families living in Ecuador. Getting closer to food sovereignty with civil action? Unpublished Master's thesis. Humboldt Universität Zu Berlin.

MAGAP [Ministerio de Agricultura, Ganadería, Acuacultura y Pesca] (2016) La política agropecuaria Ecuatoriana: Hacia el desarrollo territorial sostenible: 20152025 I Parte. Quito, Ecuador.

Mertens, E., Van't Veer, P., Hiddink, G.J., Steijns, J.M., \& Kuijsten, A. (2016) Operationalising the health aspects of sustainable diets: A review. Public Health Nutrition, 20(4), pp. 1-19.

MIES, CEPAL \& Programa Mundial de Alimentos (2017) Impacto social y económico de la malnutrición. Resultados del estudio realizado en Ecuador. Available at: http://es.wfp.org/sites/default/files/es/file/el_costo_de_la_doble_ carga_de_la_malnutricion_-_ecuador.pdf.

Ministerio de Cultura y Patrimonio (2013) Patrimonio alimentario. Quito, Ecuador, Fasículo 1.

Moorman, C. \& Matulich, E. (1993) A model of consumers' preventive health behaviors: The role of health motivation and health ability. Journal of Consumer Research. 20(2), pp. 208-228.

Muzo, A., Belmont, P., \& Navarrete, I. (2017) Análisis de los circuitos cortos de los productos agroecológicos en el Ecuador. Ecuador, AllpaData, pp. 1-55.

Newholm, T. \& Shaw, D. (2007) Studying the ethical consumer: A review of research. Journal of Consumer Behaviour. 6(5), pp. 253-270.

Ottman, J.A. \& Reilly, W.R. (1998) Green marketing: Opportunity for innovation. 2nd edition. Upper Saddle River, NJ, Prentice Hall.

Ozçaglar-Toulouse, N. (2009) What meaning do responsible consumers give to their consumption? An approach by narratives. Recherche et Applications en Marketing (English Edition). 24(3), pp. 3-20.

Paredes, M. (2010) Peasants, potatoes and pesticides. Heterogeneity in the context of agricultural modernization in the highland Andes of Ecuador. Unpublished Ph.D. Thesis. Wageningen University and Research Center, The Netherlands.

Peralta, E. (2016) El chocho en Ecuador. Estado del Arte. Available at: http:// repositorio.iniap.gob.ec/bitstream/41000/3938/1/iniapscdpCD99.pdf.

Peralta, E., Mazón, N., Murillo, A., Rivera, M., Rodríguez, D., Lomas, L., \& Monar, C. (2012) Manual agrícola de granos Andinos: Chocho, quinua, amaranto y ataco. 
Cultivos, variedades y costos de producción. 3rd ed., No. 69. Programa Nacional de Leguminosas y Granos Andinos. Estación Experimental Santa Catalina. INIAP. Quito, Ecuador.

Piñeiro, C. \& Díaz, M.J. (2012) Lost in the city: Responsible consumption as message, and the city of Madrid as communication ecosystem. Athenea Digital. 12(1), pp. 67-88.

Pivato, S., Misani, N., \& Tencati, A. (2008) The impact of corporate social responsibility on consumer trust: The case of organic food. Business Ethics: A European Review. 17(1), pp. 3-12.

Roberts, P., KC, S., \& Rastogi, C. (2006) Rural access index: A key development indicator. Washington, DC, The World Bank Group.

Sarandón, S.J. \& Flores, C.C. (Eds.) (2014) Agroecología: Bases teóricas para el diseño y manejo de agroecosistemas sustentables, 1st ed. La Plata, Universidad Nacional de La Plata.

Sherwood, S. (2009) Learning from Carchi. Agricultural modernization and the production of decline. Unpublished Ph.D. Thesis. Wageningen University and Research Center, The Netherlands.

Sonnino, R. (2009). Feeding the city: Towards a new research and planning agenda. International Planning Studies. 14(4), pp. 425-435.

Stern, P.C. \& Dietz, T. (1994) The value basis of environmental concern. Journal of Social Issues. 50(3), pp. 65-84.

Subsecretaría de Agricultura (2015) Datos Referenciales. Quito, Ecuador, Ministerio de Agricultura, Ganadería, Acuacultura y Pesca.

Suquilanda, M. (2006) Agricultura orgánica. Alternativa tecnológica del futuro. 3rd ed. Quito, Ecuador, Fundación para el desarrollo agropecuario.

Tsai, Y.H., Joe, S.W., Lin, C.P., Chiu, C.K., \& Shen, K.T. (2015) Exploring corporate citizenship and purchase intention: Mediating effects of brand trust and corporate identification. Business Ethics: A European Review. 24(4), pp. 361-377.

Unigarro Solarte, C. (2010) Patrimonio cultural alimentario. Quito, Ecuador, Fondo Editorial Ministerio de Cultura. Cartografía de la memoria no 4.

Villacrés, E., Navarrete, M., Lucero, O., Espín, S., Peralta, E. (2010) Evaluación del rendimiento, características físico-químicas y nutraceúticas del aceite de chocho (Lupinus mutabilis sweet). Revista tecnológica ESPOL-RTE. 23(2), pp. 57-62.

Warde, A. (2005) Consumption and theories of practice. Journal of Consumer Culture. 5(2), pp. 131-153.

Webster, F.E. (1975) Determining the characteristics of the socially conscious consumer. Journal of Consumer Research. 2(3), pp. 188-196.

Yépez, R., Carrasco, F., \& Baldeón, M. (2008) Prevalencia de sobrepeso y obesidad en estudiantes adolescentes ecuatorianos del área urbana. Archivos Latinoamericanos de Nutrición. 58(2), pp. 139-143.

Zimmer, M., Stafford, T., \& Stafford, M. (1994) Green issues: Dimensions of environmental concern. Journal of Business Research. 30(1), pp. 63-74. 